\title{
Assessing Communication Skills among Jordanian Tour Guides: German Tourists Perceptions
}

\author{
Ehab Abdul Raheem Alshatnawi \\ Travel and Tourism Management, Faculty of Tourism and Hospitality \\ The University of Jordan $\backslash$ Aqaba \\ E-mail: eh_sh_2000@yahoo.com
}

Received: Oct. 1, 2013 Accepted: November 15, $2013 \quad$ Published: January 1, 2014

doi:10.5296/jmr.v6i1.4361 URL: http://dx.doi.org/10.5296/jmr.v6i1.4361

\begin{abstract}
The study aims to identify the communication skills to be available at Jordanian tour guides and how German tourists assess these skills. The analytical descriptive approach was used in the current study (survey and analysis). This approach is based on collecting data, organizing and analyzing it. The study mainly addressed how German tourists assess communication skills among Jordanian tourist guides.

Results of the study revealed that Jordanian tourist guides possess communication skills in different degrees to perform his tasks. The study recommended the need for promoting tour guides communication skills on periodical basis and not stop in the point they have reached.
\end{abstract}

Keywords: Assessment, Communication skills, Tour guide. 


\section{Introduction}

Jordan has become one of the most important tourist destination in the Middle East, especially for foreign tourists. Tourism is one of the key drivers for the Gross Domestic Product (GDP) for Jordan, one of the most important contributors in raising national income and attracting hard currency. In 2012, the contribution of Tourism sector in Jordan in the GDP was estimated by $13 \%$ of the total GDP. Furthermore, the tourism sector represents one of the most important workforce operator in Jordan by providing new work vacancies as the workers in the tourism sector totaled (43.781) according to the statistics provided by Tourism and Antiquities Ministry in Jordan (2012).

The tour guide profession is considered one of the most important professions in the tourism sector. Tour guides are the façade of the state they represent, represent all the people living in the state, reflect the attitudes, traditions and ideas they hold. Also, they are the only liaison between the tourism companies, tourism transportation companies, restaurants, hotels and other tourism facilities and the tourist. Tour guides are the persons who spend most of the time with the tourist and consequently, they are to understand the specific needs of tourists, work to fulfill these needs combined with the ability to present the different issues in an interesting manner for tourists (Al Maqableh, 2000).

Jordan has witnessed great developments in the tourism sector in the tourism offers as different services and facilities are now provided for tourists including tour guiding. As a result, the number of tour guides in Jordan has increased significantly as it was only (144) tour guide in 1989 to become (1150) in 2012 (Tourism and Antiquities Ministry in Jordan Brochures).

\section{Problem of the Study}

Tour guiding is one of the key pillars for the success of the tourism sector as it is one of the important tourism services and facilities provided for the tourist. As such, it is a major player in tourism. Tour guides are the most influential factor on tourists as they are in a direct contact with the tourist and tourists make their personal impressions about the country they visited through their interactions with tour guides.

As such, tour guides must possess specific skills and attributes. As Jordan has become one of the most important destinations in the Middle East in general, and in the numbers of German tourists in particular, the problem of the current study is addressed through answering the following questions:

1- How do German tourists assess communication skills possessed by the tour guide?

2- What are the most significant skills tour guides must possess and master to effectively interact with tourists?

\section{Significance of the Study}

The significance of the study emerges from the following:

1- The important role played by tour guides in general, and the importance of the German 
market in particular as this market is one of the promising tour markets for Jordan as German tourist totaled (38.083) in 2012 (Tourism and Antiquities Ministry in Jordan Brochures). These numbers indicate the importance of German tourists for the Jordanian tourism sector.

2- The current study addressed the communication skills Jordanian tour guides must have and master from the perceptions of German tourists, and this topic is one of the important issues in tourism literature, yet understudied in the theoretical tourism literature.

\section{Objectives of the Study}

The study aimed to :

1- Identify the most important skills and attributes that tour guides in Jordan must possess to perform their responsibilities effectively.

2- Identity communication skills that tour guides in Jordan possess and how German tourists assess them.

3- Suggest some recommendations and suggestions that may help Jordanian tour guides develop their communication skills and thus developing tour guiding as a profession.

\section{Design of the Study}

The analytical descriptive approach was used in the current study (survey and analysis). This approach is based on collecting data, organize and analyze it, then presenting the phenomenon to be studied and examined to identify the variables of the phenomenon, its causes and the related factors, then eliciting results through identifying the relationships between the variables.

\subsection{Sample of the Study}

Sample of the study consisted of (590) German tourist visiting Jordan in 2012. The sample was selected using simple random sampling procedures to achieve the objectives of the study and (567) usable questionnaires were returned. Questionnaires were distributed on the participants after they finished their tours.

\subsection{Instrument of the Study}

A questionnaire in German was prepared to achieve the objectives of the study by reviewing the related previous studies. The researcher developed the questionnaire distributing on two sections: the first section aimed to collect demographic information from the sample of the study while the second section aimed to measure the variables examined in the context of the current study.

The researcher used a 5 point Liker scale (strongly disagree $=1$, disagree $=4$, neither agree nor disagree $=3$, agree $=4$, strongly agree $=5$ ) for scoring the questionnaire.

\subsection{Validity of the Instrument}

To validate the instrument of the study, it was given to a group of specialists to give their opinions about the clarity of the items and if these items are measuring the constructs 
declared in the objectives of the study. After collecting the questionnaires from these specialists, there was an agreement between them about the suitability of the items, and the respondent took their suggestions into consideration as items needing paraphrasing were paraphrased and a cut score for the agreement or the disagreement.

\section{Previous Studies}

Several studies have examined tour guiding, but few of these studies have attempted to examine tourists' perceptions about the tour guide. These few studies are as follows:

(Judith N. Martin and Kevin K.F Wong,2001): this study examines the nature of tour guiding in Hong Kong, assessing the existing level of professional service standards, and identifying issues and challenges facing the profession in the 21 st century. Based on the findings, a set of recommendations was formulated. key recommendation includes the establishment of a monitoring system to ensure high standards of service performance by the tour guides. It is recognized that the experiences faced by the Hong Kong tour guides are unlikely to be unique and there may be some issues and problems raised that are common to the guiding profession in most other countries.

(Ways, 2003): this study recommended the need to work on promoting tour guiding field and that government agencies in the Arab World must work on developing tour guiding, prepare effective and well prepared tour guides. The study concluded with the rights, responsibilities and skills to be available at tour guides.

(Maqableh, 2004): the study aimed to identify the status of tour guiding as a profession in Jordan and to assess the educational and professional programs provided to tour guides and to how extent they are able to provide needed knowledge and skills for tour guides. The study recommended that more focus must be paid to the practical aspect of these programs and to deliver some professional courses that tour guides feel they are lack the appropriate knowledge about them.

(Hanging Q. Zhang and Ivy Chow,2004): this study assesses the performance of Hong Kong's tour guides as perceived by mainland Chinese outbound visitors. Twenty pertinent tour guide service quality attributes are identified. The results of IPA illustrate that Hong Kong's tour guides performed well in 11 out of the 20 service quality attributes, in areas mainly related to their professional skills, reliability and language ability (keep up the good work quadrant), while the problem-solving ability of Hong Kong's tour guides fell into the concentrate here quadrant.

(Denis Lecher and Judith N. Martin, 2004): in this study, The primary goal of this paper is to examine cross-national variations in the perceived importance of communication competencies of tour guides. Results indicate that there are significant differences in the perceptions of important communication competencies among the three nationality groups. For the most part, the French and German tourists ranked the dimensions differently from the American tourists. That is, the Americans ranked most nonverbal and verbal competence behaviors as more important than the European tourists did. 
(A1 Four, 2006): in this study, the researcher identified the significance of tour guides as one of the major elements in the tourism process. Sample of the study consisted of a group of tour guides in Jordan. Results of the study indicated the importance of qualifying tour guides in Jordan as they play a vital role in the development of tourism sector.

(Al Maqableh and Haddad, 2008): the study indicated that Jordanian tour guides feel that they lack the needed knowledge in the religious, environmental, political issues in addition to lack of knowledge about the international organizations. The study recommended the need for tour guides preparation program to more focus on the scientific knowledge needed, to organize training courses to enable tour guides acquire the needed information in the issues they feel ill prepared, that Tour Guides Association in Jordan to work on promoting the efficiency of tour guides by collaborating with some public agencies interested in Jordan.

(Haiyan Kongab, Catherine Cheungc \& Tom Baumd, 2009) :This article aims to develop a profile of the educational attainments, skills and attitudes, career needs, and plans of tour guides in China based on a study of both permanent and freelance guides. The findings indicate that tour guides are ill-prepared for the booming tourism industry. To attract and retain qualified guides, a focus on career management and training qualifications should be regarded as an urgent priority in human resources strategies.(Songshan Huang1, Cathy H. C. Hsu2 and Andrew Chan3, 2010): This study examines tour guide performance and its relationship with tourist satisfaction in the context of package tours in Shanghai. Tourist satisfaction was conceptualized to include three aspects/layers: satisfaction with guiding service, satisfaction with tour services, and satisfaction with the overall tour experience. Tour guide performance was found to have a significant direct effect on tourist satisfaction with guiding service and an indirect effect on satisfaction with tour services and with tour experience.

(Huang, Songshan, 2010): This study applied a modified importance-performance analysis (IPA) to evaluate tour guide performance in China from both domestic visitors' and foreign English-speaking visitors' perspectives. The results suggest that tour guides in China should improve their proficiency in guiding languages.

\section{Communication Skills and Tour Guides}

Human communication assumes several functions for man as it is a means for social, cultural and economic development and change. As the development and change opportunities expand, the need for new information, experiences and ideas increases, and thus; there is a need for effective communication channels to deliver the message for individuals and groups (Abu- Arkoub, 1993).

Communication is defined as mutual interactive process between the sender of the message and the recipient of this message. The communication message targets all individuals and groups. There are different meanings for the communication process such as that it includes all the processes people use to influence others. It is also the process by which the individual transmits specific meanings, information or ideas to others using written, verbal messages combined with facial expressions or body language or by using a communication channel 
transmitting the communication channel to another person who in turn responses to it as hel she understood (Hanna, 1992).

The sender of the message is influenced by the way he $\backslash$ she understood the message, how he $\backslash$ she judged it; and the recipient is influence in his understanding of the content of the message by his $\backslash$ her psychological state, the mental conformity between his $\backslash$ her and the sender of the message. Therefore, the most important conditions to be present in the message to be clearly understood is clarity of the message, being easy to understand, being direct and courtesy (Abu- Arkoub, 1993). The language used in the communication process and considering the prevalent traditions and rituals in the community, being sincere and honest is the most important factors in the success of the communication process (Filett, 2000).

To make an effective communication, one must take into consideration the fact that communication is basically an interactive mutual process based on human emotions. There is a need to determine the objective of the communication process in advance and to consider how the other individual in the communication process interprets these objectives and respond to them. Before the communication process takes place, one must identify the things stimulating interest at the recipient, know the things irritating him $\backslash$ her, make him $\backslash$ her suspicious. The language of emotions is more convincing than the language of rational in most cases (Al Manar Guide, 2005).

A tour guide is the person guiding tourists and escorts them to different tourism and archeological places in Jordan and providing them with the needed information about these places (article (1) of the Tour Guides Booklet). The European Authority for European Measures indicated that a tour guide is person guiding people using the language they select while explaining the cultural and natural heritage of the tourism destination.

For a tour guide to be able perform his work professionally, he has to possess several attributes such as being confident, enthusiastic, active, energetic, sensitive, observable, sensitive to others' arguments, open to other perspectives, humor, knowledgeable, good communication skills, organized, decisive in exceptional and emergency situations, good physical health and being attractive (A1 Maqableh, 1999).

\section{Data Analysis}

\subsection{Demographic Variables of the Participants:}

Table (1) provides the frequencies, percentages for the sample of the study as the majority of the sample was male (60\%), most of them (36\%) fell in the age group (more than 51 years), and the least (11\%) were in the age group (20-30). As for the marital status of the sample, the majority of the sample participants was single (38\%). As for the educational level, the majority $(49 \%)$ was secondary school certificate or less and the least percentage in this category was from $\mathrm{PhD}$ holders (3\%). 
Table 1. Frequencies, Percentages for the Demographic Variables

\begin{tabular}{|c|c|c|}
\hline 1- Gender & Frequency & Percentage \\
\hline Male & 344 & $60 \%$ \\
\hline Female & 225 & $40 \%$ \\
\hline \multicolumn{3}{|l|}{ 2- Age } \\
\hline $20-30$ & 65 & $11 \%$ \\
\hline $31-40$ & 109 & $19 \%$ \\
\hline $41-50$ & 189 & $33 \%$ \\
\hline More than 51 & 206 & $36 \%$ \\
\hline \multicolumn{3}{|l|}{ 3- Marital status } \\
\hline Single & 216 & $38 \%$ \\
\hline Married & 198 & $35 \%$ \\
\hline Other & 155 & $27 \%$ \\
\hline \multicolumn{3}{|l|}{ 4- Qualification } \\
\hline $\begin{array}{c}\text { Less than Secondary school } \\
\text { certificate }\end{array}$ & 279 & $49 \%$ \\
\hline $\mathrm{BA}$ & 239 & $42 \%$ \\
\hline MA & 35 & $6 \%$ \\
\hline $\mathrm{PhD}$ & 16 & $3 \%$ \\
\hline
\end{tabular}

\subsection{Second: Means, Standard Deviations for the Study Sample Responses on the Items}

Table no. 2 reveled that all the items have got a mean above 2.5, with significant level less than 0.05 that all these paragraphs statistically significant.

The first place was replaced by paragraph 2, which measures The tour guide is enthusiastic in his job with a mean 4.35, either paragraph No. 9 came in second place and last in paragraphs accepted statistically and a mean 3.32 .

There was an apparent satisfaction among German tourists with respect to the performance of Jordanian tour guides as the German tourists have indicated that guides have the needed communication skills as they have a strong personality to perform his job, enthusiastic, confident, sensitive, flexible, have adequate knowledge of traditions and rituals. Furthermore, they were able to speak German fluently and clearly, able to pronounce German clearly, uses the microphone effectively, have the ability to organize their work hours, and follow rules and regulations.

As seen in table (2), the means of all tables exceeded (3.00) and were lesser than the statistical significance of $(\alpha=0.05)$ and this means that they are significant.

Item (2) indicating that tour guide is enthusiastic ranked first $(M=4.35)$, while item (2) pertaining to tour guides knowledge of traditions and rituals ranked second, then $17,10,14$, $13,15,6,19,1,16,20,21,18,5,4,3,7,8,11,12$, respectively. 
Table 2. Means, Standard Deviations for the Study Sample Responses on the Items

\begin{tabular}{|c|c|c|c|c|c|}
\hline Item & Frequency & $M$ & $S D$ & $\begin{array}{c}t \\
\text { value }\end{array}$ & $\begin{array}{c}P \\
\text { value }\end{array}$ \\
\hline The tour guide has a strong personality to perform his job & 569 & 4.13 & 0.67 & 12.51 & 0.00 \\
\hline The tour guide is enthusiastic in his job & 569 & 4.35 & 0.58 & 17.08 & 0.00 \\
\hline The tour guide is highly confident & 569 & 3.96 & 0.84 & 8.53 & 0.00 \\
\hline The tour guide is sensitive & 569 & 4.00 & 0.51 & 14.57 & 0.00 \\
\hline The tour guide is flexible & 569 & 4.02 & 0.68 & 11.10 & 0.00 \\
\hline The tour guide has an attractive professional appearance & 569 & 4.16 & 0.96 & 9.01 & 0.00 \\
\hline The tour guide has various knowledge & 569 & 3.93 & 0.69 & 9.97 & 0.00 \\
\hline $\begin{array}{l}\text { The tour guide has an adequate knowledge about the history } \\
\text { of Jordan }\end{array}$ & 569 & 3.80 & 0.93 & 6.37 & 0.00 \\
\hline $\begin{array}{l}\text { The tour guide has the adequate knowledge about the } \\
\text { traditions and rituals }\end{array}$ & 569 & 4.27 & 0.56 & 16.87 & 0.00 \\
\hline $\begin{array}{l}\text { The tour guide has an adequate knowledge about Jordan } \\
\text { political, economic, social and educational situation }\end{array}$ & 569 & 4.22 & 0.53 & 16.93 & 0.00 \\
\hline The tour guide speaks clear language & 569 & 3.51 & 0.98 & 3.86 & 0.00 \\
\hline The tour's guide pronunciation is clear & 569 & 3.32 & 1.33 & 1.62 & 0.03 \\
\hline $\begin{array}{l}\text { The tour guide has good eye contact skills and uses body } \\
\text { language, low volume and facial expression while } \\
\text { communicating }\end{array}$ & 569 & 4.20 & 0.52 & 17.00 & 0.00 \\
\hline The tour guide can use the microphone effectively & 569 & 4.22 & 0.53 & 16.93 & 0.00 \\
\hline The tour guide is punctual & 569 & 4.18 & 0.77 & 11.35 & 0.00 \\
\hline $\begin{array}{l}\text { The tour guide has the ability to regulate his work hours } \\
\text { effectively }\end{array}$ & 569 & 4.13 & 0.47 & 17.65 & 0.00 \\
\hline $\begin{array}{l}\text { the tour guide asks forgiveness from the tourists whenever he } \\
\text { is late }\end{array}$ & 569 & 4.24 & 0.74 & 12.32 & 0.00 \\
\hline The Jordanian tour guide is an ideal guide & 569 & 4.05 & 0.65 & 12.03 & 0.00 \\
\hline The tour guide is able to manage emergency situations & 569 & 4.15 & 0.70 & 12.05 & 0.00 \\
\hline The tour guide respects the tourists & 569 & 4.11 & 0.90 & 9.18 & 0.00 \\
\hline The tour guide respects rules and regulations & 569 & 4.09 & 1.01 & 8.05 & 0.00 \\
\hline
\end{tabular}

\section{Result}

1- The tour guide communication skills are influenced by the environmental factors, the related surrounding conditions, the circumstances the tourist lives while staying in the tourist 
destination and these include the geographical, climate, historical variables in addition to the prevalent traditions, customs and rituals and so on.

2- The behavior of tour guides and their skills are a directed purposeful activity to achieve predetermined objectives.

3- To abandon tour guides' negative behaviors seen by the tourist as unacceptable needs collaborative efforts by professionals and those responsible of the tourist sector in Jordan and this requires organizing training programs seminars and other professional development activities for tour guides.

4- Human communication represents an important element in the work of tour guides, as it is an effective tool for changing, development and the interaction between individuals and groups, and the social, cultural and economic change.

5- The tour guide communication skills are influenced by a set of balanced and interactive factors attributable to the personality of the tour guide and the different biological, perceptive and emotional functions.

\section{Recommendations}

Based on the results reported in this study, the study suggested the following recommendations:

1- There is a need to work on promoting guides' communication skills on periodical basis and not be satisfied with the level they have reached.

2- There is a need to promote guides' language proficiency to make them use the language more effectively and to pronounce the words more clearly to be understandable for everyone as this domain had a means score of (3.32) and this value is relatively law.

3- Jordanian tour guides, especially those working with German tourists, have to increase their knowledge about Jordan as this domain had a means score of (3.80) and this value needs to be increased.

4- Jordanian tour guides must possess a thorough cultural knowledge about the different topics in Jordan, especially those topics that interest the tourists visiting Jordan. As a result, the Jordanian tour guide may leave a good impression reflecting the civilized picture of Jordan.

5- There is a need to organize training programs and to organize qualification courses for the old tour guides in Jordan and these must be mandatory for all working in the tourism sector. These are to keep abreast with the new developments in the different fields.

6- Preparing a training program based on the required scientific evidences to improve the current communication skills tour guides possess.

7- The Tour Guides Association in Jordan has the responsibility of issuing periodicals addressing the latest statistical and archeological advances in Jordan, provide tour guides 
with the latest information by the collaboration between the Tour Guides Association and public and private organizations working in the tourism sector.

8- Future research examining other tour guides communication skills working with tourists other than German is needed.

\section{References}

Abu Arkoub, Ibrahim. (1993). Human Communication and its Role in social Interaction. Amman- Dar Majdalawi for Publications and Distribution.

Al Faouri, Subhi. (2006). Tour Guiding: Theory and Practice. $1^{\text {st }}$ Ed., Al Waraq for Publications and Distribution, Amman- Jordan.

Al Maqableh, Khaled, \& Haddad, Rafah. (2008). Local Communities Perceptions for the Jordanian Tour Guide Role in the Tourism Development. Jordanian Journal for Social Sciences, 61(1).

Al Maqableh, Khaled. (1999). The Art of Tour Guiding. Amman- Dar Wael for Publications and Distribution.

Al Maqableh, Khaled. (2000). The Fundamentals of Tourism Industry. Tourism and Hotels Series, 6 .

Al Maqableh, Khaled. (2004). How Do Tour Guides Assess their Training Programs. Human and Social Sciences, 4(1).

Awais, Ghasan. (2003). Tour Guiding: A Science and an Art. $1^{\text {st }}$ Ed., Dar Zahran, AmmanJordan.

Denis Leclerc \& Judith N. Martin. (2004) Tour guide communication competence: French, German and American tourists' perceptions. International Journal of Intercultural Relations, 28(3-4), 181-200.

Fillet, Van James. (2000). The Permanent Guide for Success with People. Al Riyadh, Jarir Library.

Haiyan Kongab, Catherine Cheungc, \& Tom Baumd. (2009). Are Tour Guides in China Ready for the Booming Tourism Industry?,Journal of China Tourism Research, 5(1), 65-76. http://dx.doi.org/10.1080/10941665.2012.724018.

Hanqin Q. Zhang \& Ivy Chow. (2004) Application of importance-performance model in tour guides' performance: evidence from mainland Chinese outbound visitors in Hong Kong. Tourism Management, 25(1), 81-91.

Huang, Songshan. (2010). A Revised Importance-Performance Analysis of Tour Guide, Tourism Performance Analysis, 27-241. http://dx.doi.org/10.3727/108354210X12724863327803

Judith N. Martin \& Kevin K.F Wong. (2001). Case study on tour guiding: professionalism, issues and problems. Tourism Management, 22(5), 551-563 


\section{Macrothink}

Journal of Management Research ISSN 1941-899X 2014, Vol. 6, No. 1

Michael S. Hanna. (1992). Introduction to Human Communication, WN. C. Brown Publish.

Songshan Huang, Cathy H. C. Hsu, \& Andrew Chan. (2010). Tour Guide Performance and Tourist Satisfaction: a Study of the Package Tours in Shanghai, Journal of Hospitality \& Tourism Research, 34(1), 3-33. http://dx.doi.org/10.1177/1096348009349815

Ting-Yuan Chang, Shiann-Far Kung, \& Ding-Bang Luh. (2012). The innovative service model: a study on tour guide service design in taiwan, application. Academic Research International, 2(1). ISSN-L: 2223-9553, ISSN: 2223-994. 